\title{
THE ANALYSIS OF ENTREPRENEURIAL INTENTION IN RURAL AREA: A CASE STUDY OF BUKIT PERAMUN GEOSITE IN INDONESIA
}

\author{
Risa BHINEKAWATI* \\ Sekolah Tinggi Manajemen IPMI, Business and Management Program, \\ Jl. Rawajati Timur I/1, Jakarta 12750, Indonesia, email: risa.bhinekawati@ipmi.ac.id \\ Liza Agustina Maureen NELLOH \\ Sekolah Tinggi Manajemen IPMI, Business and Management Program, \\ Jl. Rawajati Timur I/1, Jakarta 12750, Indonesia, email: liza.nelloh@ipmi.ac.id \\ Oman ABDURAHMAN \\ Bandung Geological Museum, Geological Agency, Ministry of Energy and Mineral Resources, \\ Jl. Diponegoro No. 57, Bandung, Jawa Barat, Indonesia, email: omanarah@gmail.com
}

Citation: Bhinekawati, R., Nelloh, L.A.M., \& Abdurahman, O. (2020). THE ANALYSIS OF ENTREPRENEURIAL INTENTION IN RURAL AREA: A CASE STUDY OF BUKIT PERAMUN GEOSITE IN INDONESIA. GeoJournal of Tourism and Geosites, 28(1), 80-94. https://doi.org/10.30892/gtg.28106-453

\begin{abstract}
A geosite inherits geological heritage which brings rural entrepreneurship potentials. This study aims to investigate the relationships between social norms, subjective norms, perceived behavioural control (PBC) and entrepreneurial intention of villagers of Bukit Peramun geosite in Belitong Geopark, Indonesia. Structural Equation Model with Partial Least Square is employed to analyze the questionnaires from 100 local residents surrounding the geosite. The study finds that social norms have positive and significant effect on subjective norms, but no direct effect on PBC. Both PBC and subjective norms have positive and significant effect on entrepreneurial intention. It means that the community's views directly influence the families' and close friends' views about the importance of entrepreneurship spirits and actions. Subsequently, the families' and friends' view would affect individuals' perceptions on their entrepreneurial capabilities, which then influence their entrepreneurial intentions to do businesses and be entrepreneurs. These findings illuminate factors that influence entrepreneurial intention of villagers surrounding a geosite. This research has tested and enhanced the application of the Theory of Planned Behavior on rural entrepreneurship in the context of geopark. Lessons from this research can be replicated to other rural areas with similar characteristics.
\end{abstract}

Key words: Entrepreneurial Intention, Belitong Geopark, Bukit Peramun Geosite, Indonesia, Theory of Planned Behavior

\footnotetext{
* Corresponding author
} 
The Analysis of Entrepreneurial Intention in Rural Area:

A Case Study of Bukit Peramun Geosite in Indonesia

\section{INTRODUCTION}

Rural entrepeneurship has been seen as a way to improve rural economic development (Newbery et al., 2017). Rural entrepreneurs usually develop their business in close proximity to their residences, at least at the early stage of their entrepreneurial process (Bosma et al., 2009). With regards to rural economic development, geoparks have been developed as innovative efforts to preserve national and geological heritage and serves as local economic and cultural protection (Ardiansyah et al., 2015; DonizPaez et al., 2011; Farsani et al., 2012). UNESCO has set very high criteria for a geopark to be listed as a global geopark, including the wealth of ecological, archaeological, historical or cultural value of geosites within geopark (2018). Geoparks should be managed with integrated concept of environmental protection, education, and sustainable development involving local communities (UNESCO, 2018), so it can contribute to poverty eradication, employmnet creation, and environmental preservation in rural areas of the world (Bentivenga et al., 2019; Farsani et al., 2012). Accordingly, geoparks have been considered as one of the best forms of sustainable rural tourism that will provide jobs and productions of goods and services related to uniqueness of the geoparks ( Bentivenga et al., 2019; Farsani et al., 2012).

Indeed, geoparks have been able to generate novel ideas for business development for local people, such as geotours, geoproducts, geomuseums, geosports, georestaurant, geobakeries, hotels and health centers (Farsani et al., 2011).

Indonesia has 15 national geoparks where four of them are recognized as global geopark among 140 global geoparks in 138 countries (UNESCO, 2018). Currently, Belitong National Geopark in Indonesia is being reviewed by UNESCO to receive global geopark status. The status of this geopark is now a UNESCO Global Geopark (UGG) candidate whose dossier have been accepted by UNESCO since November 2018 (Abdurahman et al., 2019). Belitong Geopark is located approximately $400 \mathrm{~km}$ to the North of Jakarta, the capital city of Indonesia (only 1 hour by plane), and covered Belitung district and East Belitung district, Bangka-Belitung Island Province.

The geographical boundaries of Belitung island span between 107013'00" 108051'00" East longitude and 02029'30"- 03025'00" South latitude. Belitung island has a total area of approximately 4,800 km2 of land and 13,000 km2 of sea area. The geopark is situated in the Belitung island which is surrounded by 241 small islands. The name "Belitong Geopark" was chosen based on traditional and historical consideration and has been well accepted by the communities of the Belitung island (Abdurahman et al., 2019).

As shown in Figure 1, Belitong Geopark's main geology is dominated by flysh sedimentary rock, sandstone \& clayrock, Permocarbonaged or Kelapa Kampit Formation (red-green colour in the map) and Tajam Formation (red-green-blue colour); \& granite-granitic rocks (pink to red colour). The granite-granitic rocks are generally divided into two types. The S-type (Tanjung Pandan granite) which is rich in tin mineral (cassiterite), and I-type (granitic rocks namely adamelite, granodiorites, etc) that does not contain tin mineral. Although it is close to Bangka island and both have granite type rocks, are both tin producers, but the geological conditions of granite on Belitung are different from those in Bangka. Other characteristics of Belitong's geology which is not found on Bangka Island is Belitung tektite or Billitonite rocks or Batu Satam according to local residents. In sum, Belitong is the first geopark in Indonesia in the form of islands with major geological geoheritages and their values, including 1) Tor landscape of granite Belitong; 2) the unique Satam stone/Billitonite rock/Belitung tektite; 3) The variations of granite, granitic, to quartzdiorite rocks in the south end of Malaya Tin-Belt; 4). The uniqueness of the the remains and history of old tin mining in 
Indonesia; 5) Outcrops of Permoc-carbon sedimentary rocks andt heuniqueness of tin genesis; 6) Sediment out crops where typical Kerangas ecosystems grow; 7) Landscapes and of small islands around Belitung island; 8) Biogeography and relation of geological, biological and cultural diversity (Abdurahman et al., 2019).

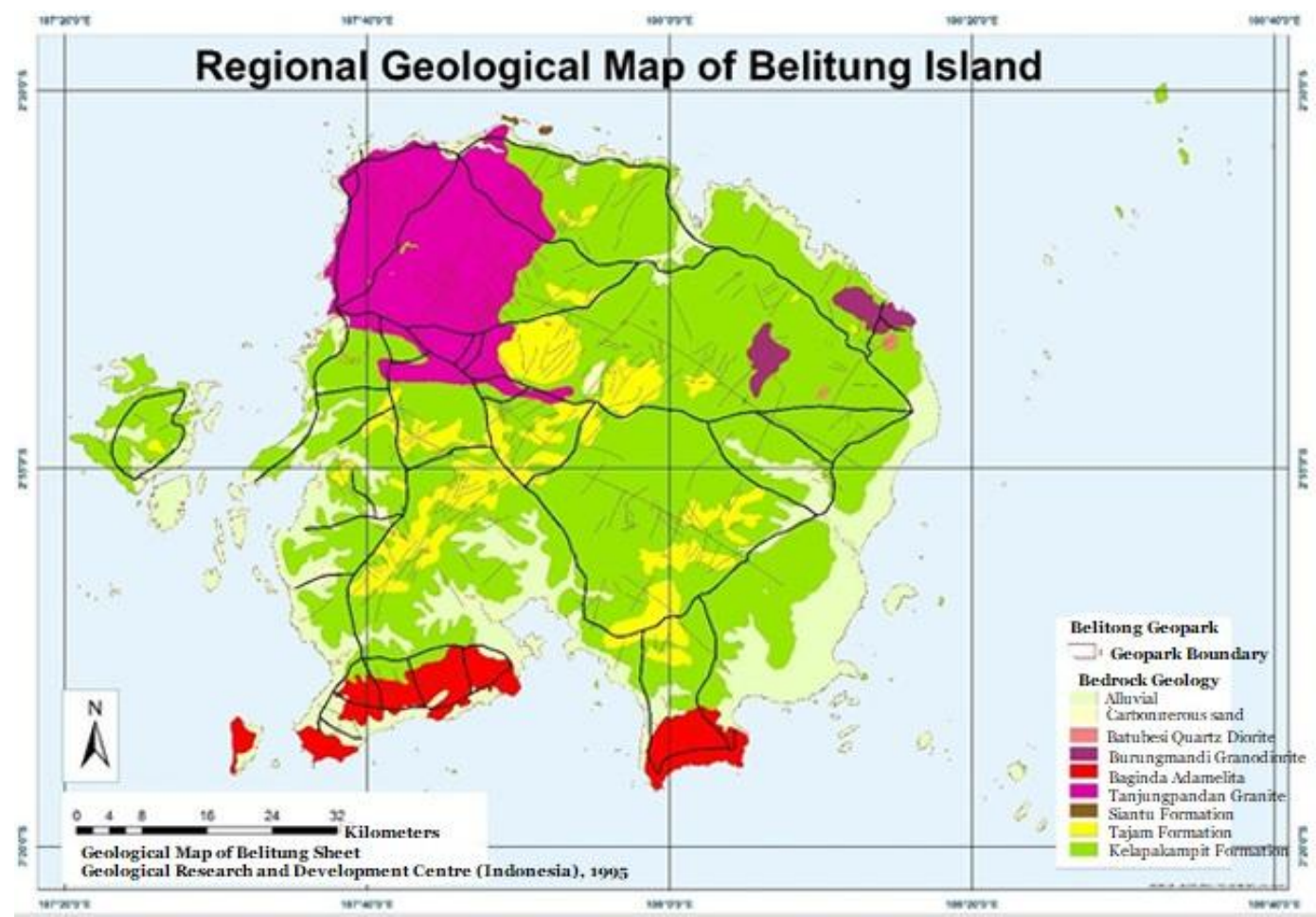

Figure 1. Geological Map of Belitong Island

(Source: Adapted from Belitong Geopark Management Agency: https://belitonggeopark.net/beranda-1)

Meanwhile, a geosite is a ground formation of geological stucture which carries the characteristics of geological heritage located inside a geopark (Çiftçi \& Güngör, 2016). According to Wimbledon (1996) and ProGEO Group (1998), a geosite is a natural structure in the forms of group of rocks, minerals or fossils, stratum, ground formation or geological structure resulting from an event during the creation or evolution of the earth's crust, that put a process or formation into existence, that has a need for scientific documentation and in some cases visual attraction qualities.

As the context of this research, one of geosites of Belitong Geopark called Bukit Peramun, located in Aik Selumar village has been chosen as a case study. Aik Selumar village, the area where Bukit Peramun (Peramun Hill) is located, was chosen as a case study for several reasons. Firstly, there is a research gap on the application of the theory of planned behavior to explain entrepreneurship development in the context of rural areas in a developing country (Gries \& Naudé, 2011; Kibler, 2013; Wilson \& Martin, 2015).

Secondly, empirical evidence is needed to explain how geoparks as a government policy affect the well-being people through economic participation in geotourism (Farsani et al., 2011). Thirdly, Belitong Geopark Agency suggested Aik Selumar as an exemplary case study for the capability to be self-organized in preserving the Bukit Peramun geosite, 
and in generating visits from domestic and foreign tourists despite limited support from the government. Fourthly, Arsel community was open to be researched. Figure 2 shows the study location, which is one among 17 geosites in Belitong Geopark.

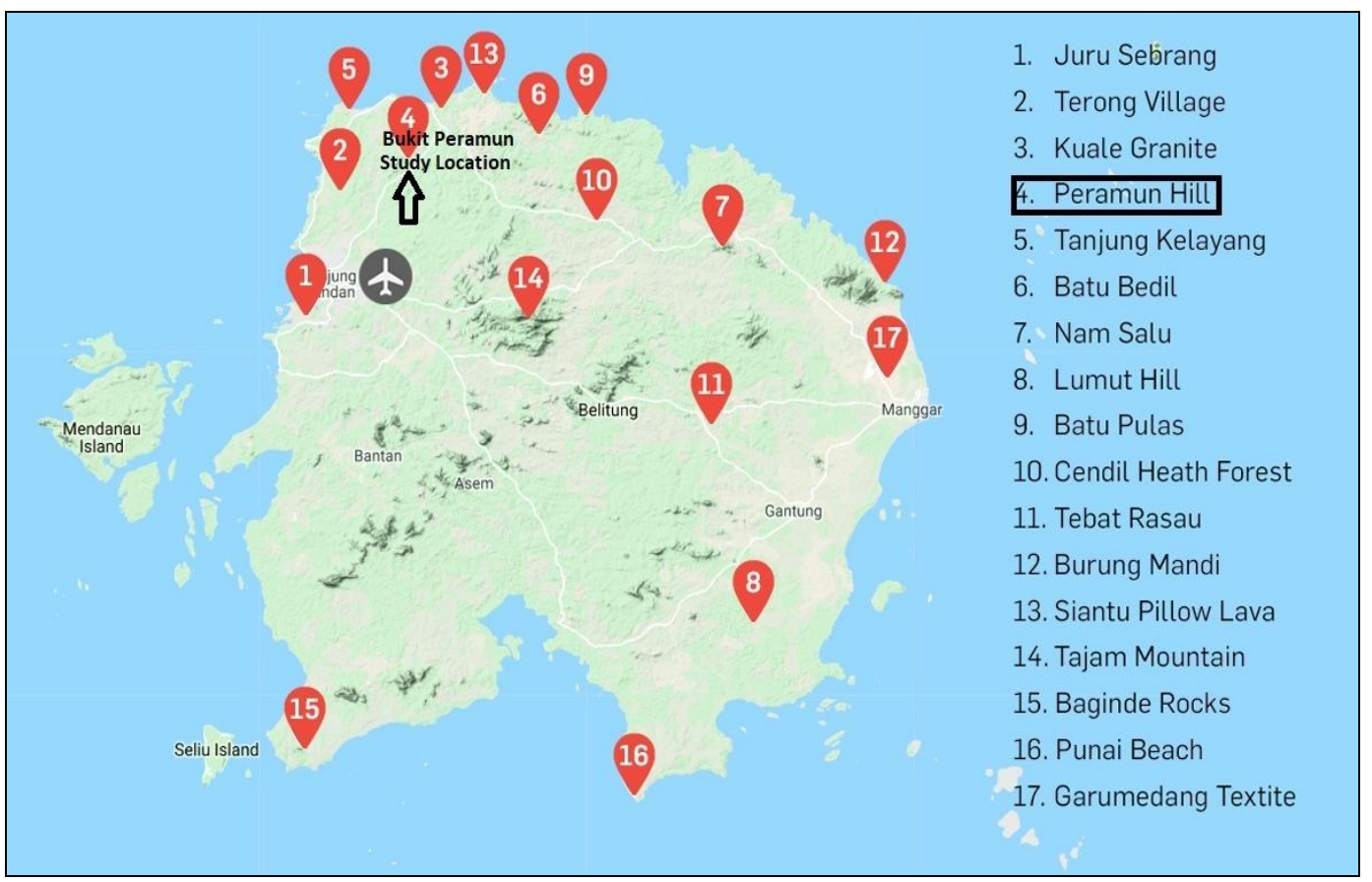

Figure 2. Location of Bukit Peramun geosite in Belitung Island

(Source: Adapted from Belitong Geopark Agency: https://belitonggeopark.net/map-2 )

Aik Selumar has a population of 2,736 inhabitants and is endowed with beautiful landscape, richness in herbal resources, a historical cultural site, a rare species of the nocturnal animal called "Tarsius" (spectral tarsier). The landscape of Bukit Peramun has unique characteristics with formations of ancient rocks of around 245 million years old, which consist of Tanjung Pandan Granite that emerged as a continuation of the "Jurassic Granite Belt" that stretches from Burma, Thailand, Malaysia, Riau Islands, Riau Islands, Bangka Island and Belitung Island to Karimata Island. Granite belts are rows of granite rock formations which are rich in mineral cassiterite (cassiterite) tin carriers which came to be known as "tin belts" (Abdurahman et al., 2019).

The area of Bukit Peramun hosts endemic biodiversity, namely Pelilean (Cephalopachus bancanus saltator), and some fishes which characterise biogeography of the Belitung island at the last maximum glacial (LMG) age. The unique kerangas forests and other ecosystem that represent typical relationship between the environment, biodiversity and culture such as treatment with herbs (Abdurahman et al., 2019; Abdurahman \& Cahyadi, 2019). The plants of Bukit Peramun have been wellknown for herbal medicine made by villagers who inherit the capabilities of formulating medicines for the plants. The government has given Aik Selumar (Arsel) community the right to manage 115 Hectares of Bukit Peramun as community forest from 2013. Since 2016 Arsel community started to offer eco-tourism with a motto "sustainability of forest generates prosperity for community”. In 2018, Bukit Peramun attracted 14.408 
domestic and international tourists (ARSEL-Community, 2018), and was chosen as one of Indonesia's 20 best eco-tourism spots by the Indonesia Sustainable Tourism Award. As an illustration of Bukit Peramun landscape, Figure $3 \mathrm{a}$ and $3 \mathrm{~b}$ show geological formations located in Bukit Peramun. Subsequently, Figures $3 \mathrm{c}$ and $3 \mathrm{~d}$ display the process of geomorphology of ancient rocks in the area.
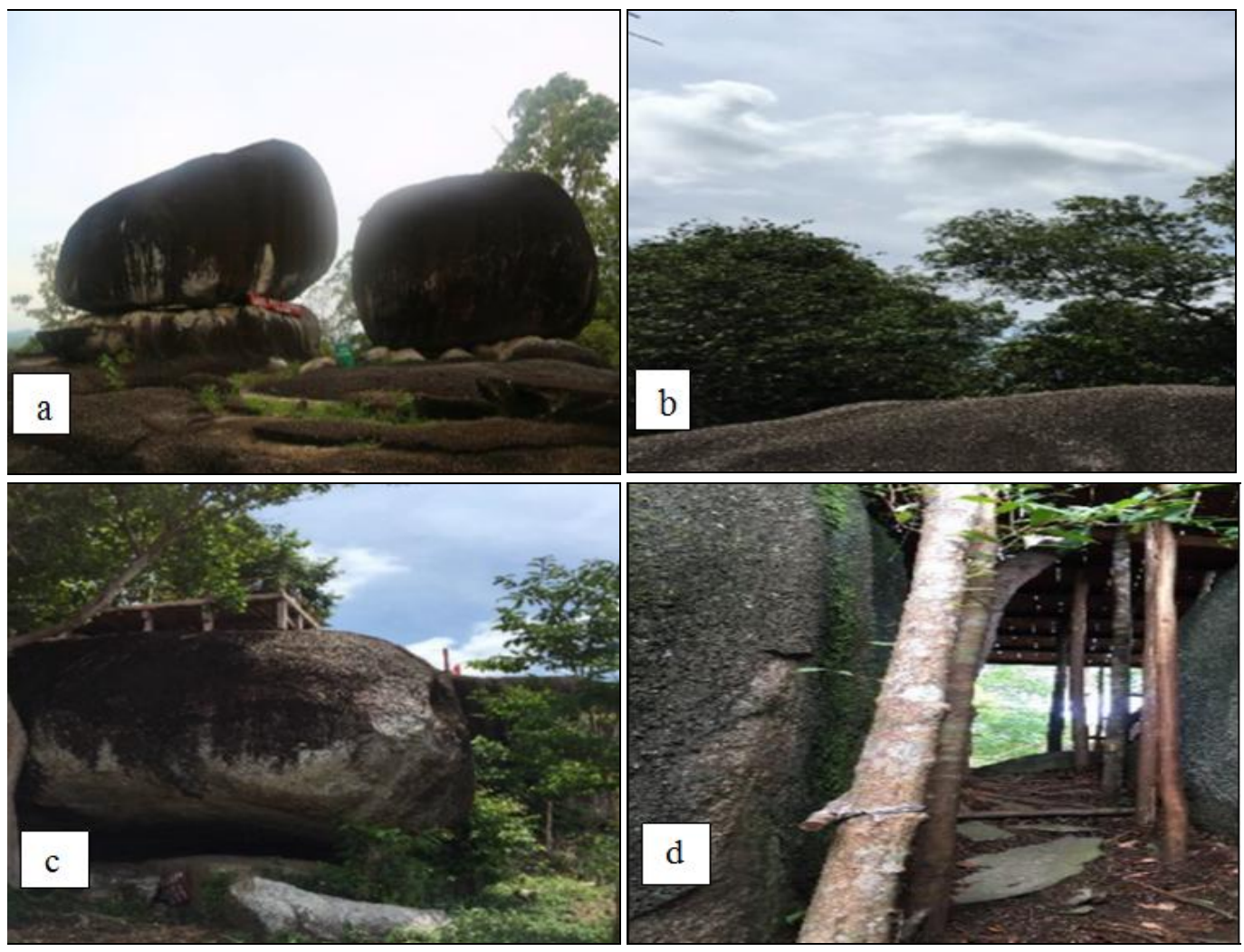

Figure 3. The balancing rock as common Tor landscape in Bukit Peramun (a); Outcrops of granite on top of Bukit Peramun (b); Erosion produces a rounded form with recesses

(c); Tectonic plus erosion which results in passageways (d) (Photocredits: Abdurahman)

Current research on rural entrepreneurship are mostly being conducted in developed countries like USA (Newbery \& Bosworth, 2014), Malaysia (Dahalan et al., 2015) and Finland (Kibler, 2013). There are also numbers of research on sustainabile community-based tourism like in Ghana (Atanga, 2019), in South Africa (Strydom et al., 2018), Romania (Vijulie et al., 2018), Indonesia (Aswita et al, 2018), and Poland (Idziak et al., 2015), as well as the roles of geoparks in rural development (Adriansyah et al., 2015; Dowling \& Newsome, 2018; Farsani et al., 2012; Yuliawati et al., 2016).

However, there is still a research gap on entrepreneurship development in rural areas surounding geosites of geoparks. To fill in the research need, this study aims to extend previous research in rural entrepreneurship development by adopting the theory of planned behaviour to investigate the relationships between social norms, subjective norms, perceived behavioural control (PBC) and entrepreneurial intention of villagers of a geosite in a Belitong geopark of Indonesia. 
The Analysis of Entrepreneurial Intention in Rural Area:

A Case Study of Bukit Peramun Geosite in Indonesia

\section{LITERATURE REVIEW AND HYPOTHESIS DEVELOPMENT}

In the context of rural development, community-based tourism has been proven to be a successful sustainable development initiative to enhance the well being of people in rural areas (Atanga, 2019; Jaafar et al., 2014; Farsani et al., 2011; Idziak et al., 2015; Strydom et al., 2018; Aswita et al., 2018; Vijulie et al., 2018). Extensive research has also been done on the roles of geotourism in improving the livelihood of people (Adriansyah et al., 2015; Dowling \& Newsome, 2018; Farsani et al., 2012; Yuliawati et al., 2016).

As discussed in the Introduction, this study aims at filling in the gap on the analysis of factors that influence entrepreneurship intention of rural people surrounding a geosite in a geopark. It focuses on variables related to entrepreneurial intentions, including social norms variable adopted from the entrepreneurial framework conditions (Reynolds et al., 2005); subjective norms and perceived behavioural control from the theory of planned behaviour (Ajzen, 1991; Ajzen \& Fishbein, 2004), and entrepreneurship intention variable from rural entrepreneurship research by Kibler (2013). The following sections discuss hypothesis development on the relationships among variables.

\section{Social Norms, Subjective Norms, and Perceived Behavioural Control}

Entrepreneurship is the result of interactions between the person and his/her social environment, including social norms (Robeyns, 2005). Social norms refer to collective representation of informal understandings that influence the behaviour of the members of society (Lapinski \& Rimal, 2005). According to Entrepreneurial Framework Conditions developed by Global Entrepreneurship Monitoring (GEM), social norms provide the context of social circumstances, opportunities, and perceptions for people in perceiving their abilities in becoming entrepreneurs that would lead to entrepreneurial actions (Reynolds et al., 2005). Social norms will influence subjective norms, which refers to perceptions of closer social environment such as family, friends, and collegues certain on somebody's perceptions about his/her actions or behaviour (Ajzen, 1991).

Hence, entrepreneurship may not automatically be functionings because it may depend on the subjective norms, whether being an entrepreneur is valued by individual's family and friends (Gries \& Naudé, 2011). Social norms may also influence somebody's perception on his/her perceived behavioral control, which refers to individual's belief whether he/she possesses the required capabilities and resources to perform certain behaviour (Kibler, 2013, p. 295). Perceived behavioural control captures a person's perception on the likelihood of easiness and successfulness if they choose to start a business (Kibler, 2013, p. 304). In the capability approach view, entreprenurial capabilities of a person relates to a person's freedom to pursue entrepreneural opportunity and it is based on the level which is afforded by individuals within their own environment (Wilson \& Martin, 2015, p. 161).

Social norms matters in individual decision in becoming an entrepreneur because individual decisions are usually influenced by his/her interactions with surrounding environment and their relations with others (Boschma et al., 2010; Sternberg, 2009). As for the relationship between subjective norms and perceived behavioural control, researchers have also find the influence of closest people such as family, friends and community in building somebody's perception of his/her capability in performing certain behavior (Liñán et al., 2011). Such relationships have also been tested by Kibler (2013) in his study on rural entrepreneurship in Finland.

Based on the above discussions, we develop the following hypotheses:

H1: Social Norms positively influence subjective norm

H2: Social Norms positively influence perceived behavioural control

$\mathrm{H}_{3}$ : Subjective norms positively influence perceived behavioural control 


\section{Subjective Norms, Perceived Behavioural Control, and Entrepreneurial Intention}

Researchers have conducted studies on the relationship between subjective norms, perceived behavioural control and entrepreneurial intention, the theory of planned behaviour (Ajzen, 1991; Ajzen \& Fishbein, 2004) in studies on entrepreneurship (Kibler, 2013; Liñán et al., 2011). They find the perceptions of family, friends and community will influence people's perception about their capabilities in conducting business or being entrepreneurial (Kibler, 2013; Liñán et al., 2011). Furthermore, previous research has also confirmed positive relationship between perceived behavioural control and entrepreneurial intention (Kibler, 2013).

Perceived behavioural control refers to individual's belief whether he/she possesses the required capabilities and resources to perform certain behaviour (Kibler, 2013, p. 295). Entrepreneurship intention is a person's drive or strong intention to start a new business, or seriously plan to open a new venture in a foreseeable future (Thompson, 2009). When sombebody believes that he or she has entrepreneurship capabilities, it is very likely that he or she also has entrepreneurial intention (Kibler, 2013). Accordingly, we can develop the following hypotheses.

H4: Subjective norms positively affect entrepreneurial intention

$\mathrm{H} 5$ : Perceived behavioural control positively affects entrepreneurial intention

\section{Conceptual Framework}

Based on the above discussion, we develop the following conceptual framework to be tested with empirical evidence from this research (Figure 4).

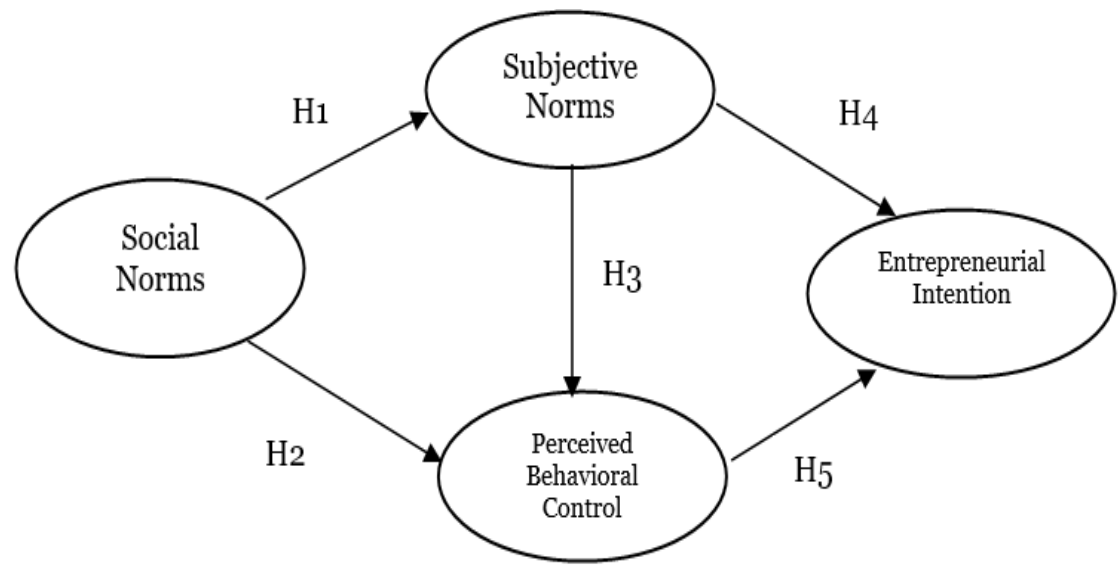

Figure 4. Conceptual Framework

\section{METHODS}

The aim of this research is to understand factors that influence entrepreneurship intention by testing the relationships between the variables of social norms, subjective norms, perceived behavioural control, and entrepreneurial intention.

Before determining the research model, we conducted a preliminary study to see the validity of variables. To test the hypotheses, the study uses Structural Equation Modeling - Partial Least Square with SmartPLS version 3.2.7 as the tool of analysis.

As for the selection of geosite, this research expands previous studies conducted by the Ministry of Tourism of Indonesia (2018) and Abdurahman, et al. (2019) which reveal that Bukit Peramun ranks 1 of 17 geosites in Belitong geopark. Both studies apply 
The Analysis of Entrepreneurial Intention in Rural Area:

A Case Study of Bukit Peramun Geosite in Indonesia

the criteria of Global Sustainable Tourism (GST) and Indonesian Sustainable Tourism Association (ISTA) on the indicators of 1) management of sustainable tourism destinations; 2) economic use for local communities; 3) cultural preservation by the public and visitors; and 4) environmental preservation.

Furthermore, Abdurahman et al. (2019) has also applied the methods developed by Newsome and Dowling (2005) and Brahmantyo (2014) to determine the uniqueness aspects of geosites, including location, geological characteristics, biodiversity, cultural diversity, knowledge value, economic value, environmental protection and preservation, geotourism potential, and the total scores fulfilled by each geosites. Based on those studies, Bukit Peramun has been seen as the most ready geosite for geotourism in Belitung, and can be served as a model of other geosites in Belitong geopark.

\section{Sampling and Study Site}

The target population of this study is the society of Aik Selumar Village in Belitung, Indonesia who intend to start a new business. As we are using SEM-PLS as the tool to analyze the data, we follow the guidelines of (Marcoulides \& Chin, 2013; Marcoulides \& Saunders, 2006) that the acceptable numbers of samples are ten times numbers of arrows pointing at latent variables As we have five arrows, the sampling size of 70 would be sufficient. However, we also follow Hoyle's (1995) suggestions that a sample size of 100 to 200 would fulfill the criteria for path modeling.

For this research we distribute a total of 120 questionnaires, divided evenly in four sub-villages of Aik Selumar. Three surveyors assisted with data collection, and we have 100 filled questionnaires which fulfilled the statistical requirement. The profile of respondents can be summarised in Table 1.

Table 1. Respondents' Profile

\begin{tabular}{|c|c|c|c|}
\hline \multicolumn{2}{|c|}{ Demographics } & Total & Percentage \\
\hline \multirow{3}{*}{ Sex } & Male & 45 & $45 \%$ \\
\cline { 2 - 4 } & Female & 55 & $55 \%$ \\
\hline \multirow{4}{*}{ Age } & $17-25$ & 15 & $15 \%$ \\
\cline { 2 - 4 } & $26-30$ & 19 & $19 \%$ \\
\cline { 2 - 4 } & $30-40$ & 25 & $25 \%$ \\
\hline \multirow{3}{*}{$\begin{array}{c}\text { Education } \\
\text { Level }\end{array}$} & $>40$ & 41 & $41 \%$ \\
\cline { 2 - 4 } & Not finish Elementary School & 6 & $6 \%$ \\
\cline { 2 - 4 } & Elementary & 27 & $27 \%$ \\
\cline { 2 - 4 } & Junior High School & 37 & $37 \%$ \\
\hline \multirow{4}{*}{ Current Job } & Senior High School & 30 & $30 \%$ \\
\cline { 2 - 4 } & Housewife & 29 & $29 \%$ \\
\cline { 2 - 4 } & Business owner & 30 & $30 \%$ \\
\cline { 2 - 4 } & Farmer & 27 & $27 \%$ \\
\hline \multirow{3}{*}{$\begin{array}{c}\text { Monthly } \\
\text { Income }\end{array}$} & Employees/Labourers & 26 & $26 \%$ \\
\cline { 2 - 4 } & IDR 2-3.5 Millions (USD 143-250) & 32 & $32 \%$ \\
\cline { 2 - 4 } & IDR 3.5-5 Millions (USD 250 -357) & 4 & $4 \%$ \\
\cline { 2 - 4 } & No Answer & 38 & $38 \%$ \\
\hline
\end{tabular}

\section{Measurement}

Previous studies have confirmed the measurement of indicators in this study. Social norms are formulated based on (Reynolds et al., 2005), while subjective norms and perceived behavioural control are derived from previous studies in theory of planned behaviour and entrepreneurial intention (Ajzen \& Fishbein, 2004; Kibler, 
2013; Liñán et al., 2011). The indicator of entrepreneurial intention is based on Kibler (2013). The indicators of variables are presented on Table 2. This study uses 5-Points Likert Scale such as 5 (Strongly agree), 4 (Agree), 3 (Neutral), 2 (Disagree) and 1 (Strongly Disagree) (Sekaran \& Bougie, 2010).

Table 2. Variables and Indicators

\begin{tabular}{|c|c|c|}
\hline Code & Variables & Indicators \\
\hline son1 & \multirow{2}{*}{$\begin{array}{l}\text { Social Norms } \\
\text { (Reynolds, et al., 2005) }\end{array}$} & $\begin{array}{l}\text { At my village, most people consider starting a new } \\
\text { business as a desirable career choice. }\end{array}$ \\
\hline son2 & & $\begin{array}{l}\text { At my village, those who succeed in starting a new } \\
\text { business have a high social status and being respected }\end{array}$ \\
\hline sn1 & \multirow{3}{*}{$\begin{array}{c}\text { Subjective Norms } \\
\text { (Ajzen \& Fishbein,2004; } \\
\text { Kibler, 2013; } \\
\text { Liñán et al., 2011) }\end{array}$} & My family suggests me to start a new business \\
\hline sn2 & & My friends advise me to be an entrepreneur \\
\hline sn3 & & $\begin{array}{l}\text { The people whom I respect suggest me to start a new } \\
\text { business in the near future }\end{array}$ \\
\hline pbc1 & \multirow{3}{*}{$\begin{array}{l}\text { Perceived Behavioural } \\
\text { Control } \\
\text { (Ajzen \& Fishbein, 2004; } \\
\text { Kibler, 2013; } \\
\text { Liñán, et al., 2011) }\end{array}$} & $\begin{array}{l}\text { If I wanted to, I could easily pursue a career as an } \\
\text { entrepreneur }\end{array}$ \\
\hline pbc2 & & $\begin{array}{l}\text { For me, starting my own firm and becoming an } \\
\text { entrepreneur would be very easy }\end{array}$ \\
\hline pbc3 & & $\begin{array}{l}\text { If I started my own business and became an } \\
\text { entrepreneur, I have chances of success }\end{array}$ \\
\hline ei1 & \multirow{3}{*}{$\begin{array}{l}\text { Entrepreneurial Intention } \\
\text { (Kibler, 2013) }\end{array}$} & I want to be an entrepreneur \\
\hline ei2 & & I wish to start a new business in the future \\
\hline ei3 & & In the near future, I plan to open a new business \\
\hline
\end{tabular}

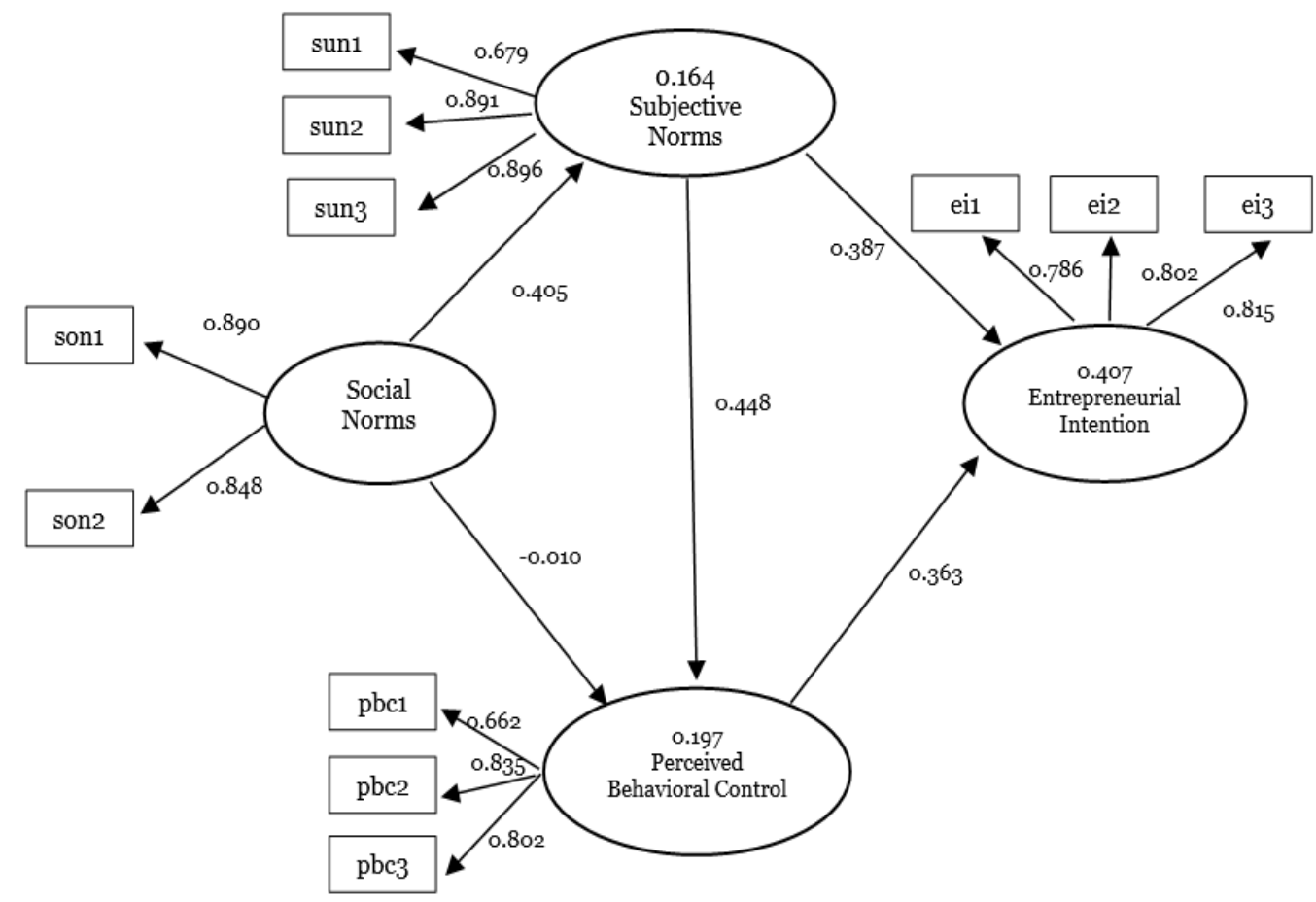

Figure 5. Loading Factor and Path Coefficient (Outer Model) 


\section{RESULTS AND DISCUSSION}

\section{Results of Validity and Reliability Testing}

To test validity we conducted several tests including covergent validity, discriminant validity, construct validity (Hair $\mathrm{Jr}$ et al., 2017). Convergent validity confirms reflective indicators on variables. To be valid, the loading factors of each item of indicators that must exceed 0.5 (Ghozali, 2006). Discriminant validity can be tested by conducting cross loading analysis to compare the outer loadings among variables. Construct validity is used to confirm that the tested variables will reflect the overal model (Ghozali, 2006). Figure 5 shows the result of the convergent and discriminant validy. It reveals the loading factors of all indictors for respective variables all are above 0.5. Moreover, as shown in Table 3, if we compare the cross loadings of between indicators' own reflect and other indicators' reflect it shows that their own reflect are higher than other indicators' reflect.

Table 3. Loading Factor Analysis

\begin{tabular}{|c|c|c|c|c|c|}
\hline Variables & Indicators & $\begin{array}{c}\text { Social } \\
\text { Norms } \\
\end{array}$ & $\begin{array}{c}\begin{array}{c}\text { Subjective } \\
\text { Norm }\end{array} \\
\end{array}$ & PBC & $\begin{array}{c}\text { Entrepreneur } \\
\text { ial Intention }\end{array}$ \\
\hline \multirow{2}{*}{ Social Norms } & Son1 & 0,890 & 0,377 & 0,160 & 0,303 \\
\hline & son2 & 0,848 & 0,325 & 0,137 & 0,158 \\
\hline \multirow{3}{*}{$\begin{array}{l}\text { Subjective } \\
\text { Norms }\end{array}$} & sn1 & 0,131 & 0,679 & 0,234 & 0,406 \\
\hline & sn2 & 0,310 & 0,891 & 0,365 & 0,422 \\
\hline & sn3 & 0,482 & 0,896 & 0,458 & 0,524 \\
\hline \multirow{3}{*}{$\begin{array}{l}\text { Perceived } \\
\text { Behavioural } \\
\text { Control (PBC) }\end{array}$} & pbc1 & 0,304 & 0,414 & 0,662 & 0,269 \\
\hline & pbc2 & 0,084 & 0,367 & 0,835 & 0,414 \\
\hline & pbc3 & 0,039 & 0,263 & 0,802 & 0,531 \\
\hline \multirow{3}{*}{$\begin{array}{l}\text { Entrepreneurial } \\
\text { Intention }\end{array}$} & ei1 & 0,061 & 0,338 & 0,435 & 0,786 \\
\hline & ei2 & 0,374 & 0,434 & 0,419 & 0,802 \\
\hline & ei3 & 0,204 & 0,527 & 0,434 & 0,815 \\
\hline
\end{tabular}

Furthermore, as presented in Table 4, the construct validity assessment shows that AVE for all latent variables are above 0.5 , hence we confirm that construct model is valid. That means, the independent and mediating variables are valid to explain the change of dependent variable (Hair Jr et al., 2017).

Table 4. Construct Validity of SEM Model

\begin{tabular}{|l|c|}
\hline \multicolumn{1}{|c|}{ Variables } & Average Variance Extracted (AVE) \\
\hline Social Norms & 0,756 \\
\hline Entrepreneurial Intention & 0,641 \\
\hline Perceived Behavioural Control (PBC) & 0,593 \\
\hline Subjective Norms & 0,686 \\
\hline
\end{tabular}

Following the validity testing, we conducted reliability testing. For the indicators to be reliable, the composite reliability should exceed $>0.7$ and Cronbach's Alpha above $>$ o.6 (Chin, 1998; Ghozali \& Latan, 2015). Table 5 reveals that all Cronbach's Alpha are above o.6; Composite Reliability are above o.8. Therefore, variables used in this research are reliable, showing that respondents reveal consistent answers to the questionnaires.

\section{Results of Coeffient Determination}

Coefficient of Determination $\left(\mathrm{R}^{2}\right)$ represents goodness of fit to prove that the model is globally accepted (Chin, 1998; Henseler et al., 2014). The results of SmartPLS 3 on Coefficient of Determination $\left(\mathrm{R}^{2}\right)$ are presented on Table 6 . The results indicate a moderate 
relationship between social norms as the exogenous variable on subjective norms and perceived behavioural control. Hence, as shown in Figure 1, 40.7\% of variance of entrepreneurial intention is explained by subjective norm and perceived behavioural control.

Table 5. Construct Validity and Reliability

\begin{tabular}{|l|c|c|}
\hline \multicolumn{1}{|c|}{ Variables } & Cronbach's Alpha & Composite Reliability \\
\hline Social Norms & 0,678 & 0,861 \\
\hline Entrepreneurial Intention & 0,722 & 0,843 \\
\hline Perceived Behavioural Control (PBC) & 0,652 & 0,812 \\
\hline Subjective Norms & 0,771 & 0,866 \\
\hline
\end{tabular}

Table 6. The Value of R-Square

\begin{tabular}{|l|l|l|}
\hline Variables & R-Square & Adjusted R-Square \\
\hline Subjective Norms & 0.164 & 0.156 \\
\hline Perceived Behavioural Control & 0.197 & 0.181 \\
\hline Entrepreneurial Intention & 0.407 & 0.395 \\
\hline
\end{tabular}

\section{Results of Hypothesis Testing}

In this research, hypothesis testing is examined through the visual diagrams and numerical assessments. The visual diagrams are depicted in Figure 5 above and in the following Figure 6. Figure 3 and Figure 4 reveal direct and indirect path relationships that show magnitude and significance of the relationships between latent variables. The above relationships are summarised in the following numerical assessment in Table 7.

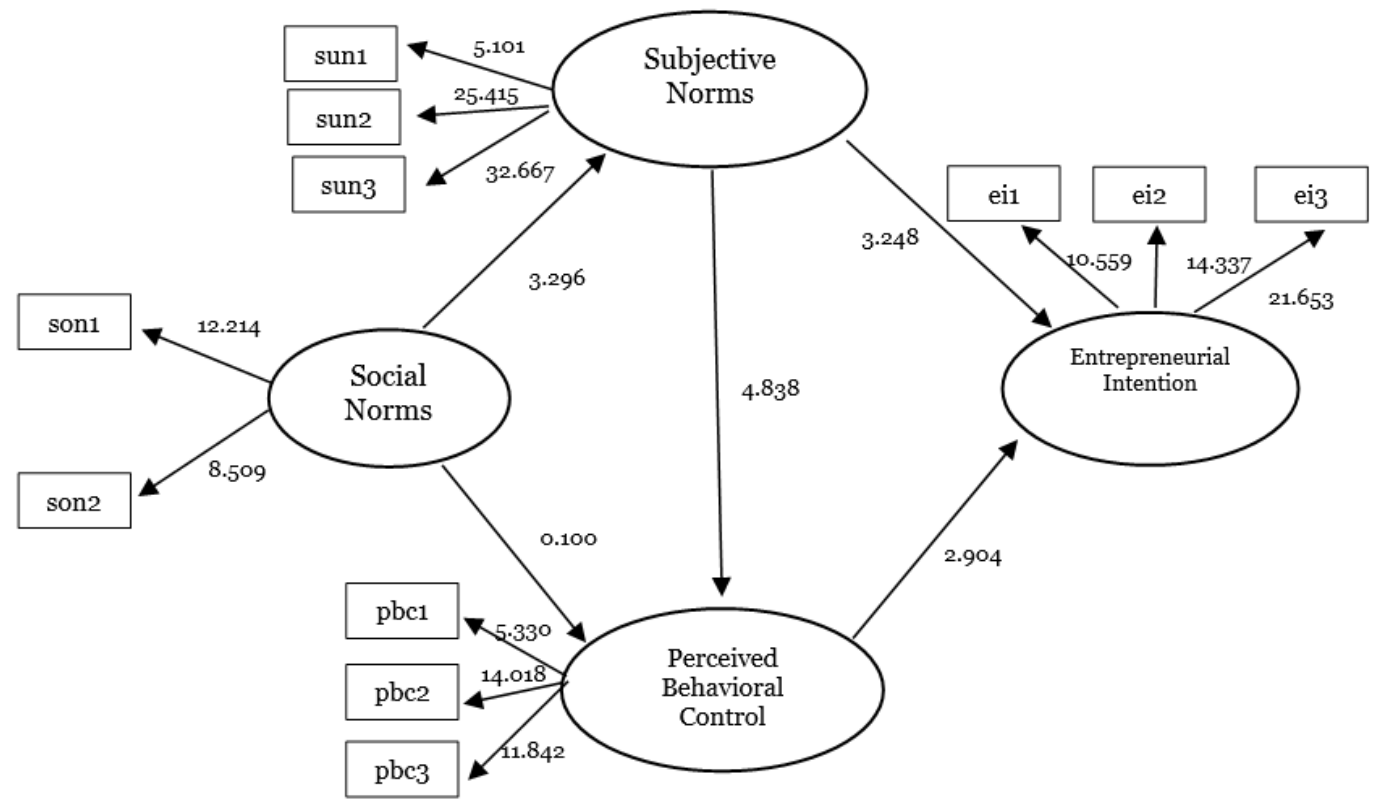

Figure 6. Structural Model (Inner Model)

\section{Discussion}

The quantitative results of this study reveals that the intention of being entrepreneurs and doing entrepreneurial work is supported by social norms, subjective 
The Analysis of Entrepreneurial Intention in Rural Area:

A Case Study of Bukit Peramun Geosite in Indonesia

norms, and perceived behavioral control. The results supports the assertions of Reynolds et al., (2005) about the impact of social norms on entrepreneurial actions; Kibler (2013) on the influence of subjective norms and perceived behavioural control of the theory of planned behaviour (Ajzen \& Fishbein, 2004) on entrepreneurial intention; and Robeyns $(2005,98)$ about the influence of social context, especially social norms, in somebody's decision making and choice on their behaviour.

Table 7. Summary of Research Hypothesis Test

\begin{tabular}{|l|c|c|c|c|}
\hline \multicolumn{1}{|c|}{ Hypothesis } & $\begin{array}{c}\text { Original } \\
\text { Sample (O) }\end{array}$ & $\begin{array}{c}\text { T Statistics } \\
(\mid \mathbf{O} / \text { STDEV } \mid)\end{array}$ & $\begin{array}{c}\text { P } \\
\text { Values* }\end{array}$ & Explanation \\
\hline Social Norms > Subjective Norm & 0,405 & 3,286 & 0,001 & Supported \\
\hline $\begin{array}{l}\text { Social Norms > Perceived } \\
\text { Behavioural Control }\end{array}$ & $-0,010$ & 0,100 & 0,920 & $\begin{array}{c}\text { Not } \\
\text { Supported }\end{array}$ \\
\hline $\begin{array}{l}\text { Subjective Norms > Perceived } \\
\text { Behavioural Control }\end{array}$ & 0,448 & 4,750 & 0,000 & Supported \\
\hline $\begin{array}{l}\text { Perceived Behavioural Control > } \\
\text { Entrepreneurial Intention }\end{array}$ & 0,363 & 2,904 & 0,004 & Supported \\
\hline $\begin{array}{l}\text { Subjective Norms > } \\
\text { Entrepreneurial Intention }\end{array}$ & 0,387 & 3,214 & 0,001 & Supported \\
\hline
\end{tabular}

* Significance at Aplha of below 0.05

Firstly, the results reveal that social norms have a positive effect on subjective norms. It means that the community of Aik Selumar influence family's and close friends' view that entrepreneurship is a valuable spirit and occupation. Secondly, the social norms have no direct effect on perceived behavioural control, meaning that the community of Aik selumar does not direcly influence somebody's perception about his/her entrepreneurship capability. Thirdly, the subjective norms have positive influence on perceived behavioural control, that means the family and friends have influence on somebody's perception on his/her entrepreneurial capability. Fourthly, Perceived Behavioural Control has significant influence on entrepreneurial intention, meaning that somebody's perception on his/her own entrepreneurial capability will affect his/her intention to do business and be an entrepreneur. Lastly, subjective norms have positive effect on entrepreneurial intention, meaning that family and close friends affect somebody's intention to do business and be an entrepreneur.

Overall, it can be concluded that in the case of Aik Selumar village, people have a better perception about their capabilities of being entrepreneurs when they work with people close to them. Hence, although the social norms are conducive for entrepreneurial environment, it only affects the norms personal circles of individuals like family and friends but does not directly affect individual's perceived entrepreneurial capabilities. The study illuminates that the personal circle (subjective norms) significantly influence individual's perception on his entrepreneurial capabilities (PBC), thus, both subjective norms and PBC affect villager's entrepreneurial intentions. The study illuminates that collaborations among villagers becomes necessity if they want to transform their entrepreneurial intention into entrepreneurial actions.

A further interview with the chief of community group revealed that the villagers have basic capabilities and local resources to pursue their entrepreneurial intention, however, they still lack skills, access to market and access to finance to transform their entrepreneurial intention into entrepreneurial actions. Good collaborations among villagers in the form of community group have attracted government, private sectors and universities to help develop Bukit Peramun. As the results, Bukit Peramun community 
has been able to develop Bukit Peramun as attractive tourist destination which has been able to atract national and international tourists. The tourism development in Bukit Peramun has provided jobs for the villagers, as tour guide with fixed income while pursuing their entrepreneurial aspirations. Eventually, Bukit Peramun was selected as role model of eco-tourism by central government and it was awarded as top 20 sustainable tourist destination in 2018 by the Indonesia Sustainable Tourism Association.

\section{CONCLUSION}

This study fills in the research needs in explaining the relationship between social context (social norms), personal context (subjective norms), perceived entrepreneurial capabilities (perceived behavioral control) and entrepreneurial intention functionings in the real setting (Gries \& Naudé, 2011; Wilson \& Martin, 2015). It extends the the findings of previous research by using the theory of planned behavior to investigate factors that influence entrepreneurial intention in the context of a geosite of a geopark.

The findings from this research can be applied to the practices of entrepreneurship development in other rural areas and geoparks. However, this research has limitations. Firstly, it covers one geosite as a case study. To enhance generalisability, further studies need to be conducted in more geosites. Secondly, the study does not test the "attitude" variable of the theory of planned behavior (Ajzen, 1991), which may limit the analysis on the relationship between overall theory of planned behavior and entrepreneurial intentions. Therefore, further research needs to be conducted to include more geosites for broader generalisability, and more variables of TPB for deeper analysis. Finally, it would also be interesting if further research is conducted to evaluate the pressure of economic development of the geosites on the forestry, which methods have been developed by Andronache et al., (2019).

\section{Acknowledgments}

This work was supported by research fund of Sekolah Tinggi Manajemen IPMI, Jakarta, Indonesia. The authors wish to thank Belitong Geopark Management Agency for advises during the research, and to $\mathrm{Mr}$ Adir Darmawan and the community of Aik Selumar (ARSEL) for the opportunity to conduct research at the community. We also would like to thank two anonymous reviewers for their helpful comments and feedback.

\section{REFERENCES}

Abdurahman, O., Erowati, D. \& Putra, H. F. (2019). Geotourism in Belitong Geopark: Enhancement of interpretation materials and proposed development of tourism destinations towards sustainable tourism. Paper presented at the 6th APGN Symposium, Rinjani-Lombok UGG, Indonesia, 20 August- 6 September, 2019.

Abdurahman \& Cahyadi (2019). Studi awal biogeografi pulau Belitung: Kasus pelilean dan ikan, sebuah upaya pengkayaan materi geowisata geopark Belitong. Paper presented at Seminar Nasional Ilmu Kebumian-Geodiversity 2019, Kebumen, Indonesia, 2 Oktober 2019.

Adriansyah, D., Busu, I., Eva, H. \& Muqtada, M. (2015). Geoheritage as the basis for geotourism development: A case study in Jeli District, Kelantan, Malaysia. GeoJournal of Tourism and Geosites, 1(15), 25-43.

Ajzen, I. (1991). The theory of planned behavior. Organizational Behavior and Human Decision Processes, 50, 179-211. https://doi.org/10.1016/o749-5978(91)90020-T.

Ajzen, I., \& Fishbein, M. (2004). Questions raised by a reasoned action approach: Comment on Ogden (2003). Health Psychology, 23, 431-434.. https://doi.org/10.1037/0278-6133.23.4.431.

Andronache, I., Marin, M., Fischer, R., Ahammer, H., Radulovic, M., Ciobotaru, A., Jelinek, H.F., Di Ieva, A., Pintilii, R., Drăghici, C., Herman, G.V., Nicula, A., Simion, A., Loghin, I., Diaconu, D. \& Peptenatu, D. (2019). Dynamics of Forest Fragmentation and Connectivity Using Particle and Fractal Analysis. Scientific Reports, 9:12228. https://doi.org/10.1038/s41598-019-48277-z 1. 
The Analysis of Entrepreneurial Intention in Rural Area:

A Case Study of Bukit Peramun Geosite in Indonesia

Aswita, D., Suryadarma, I.G.P. \& Suyanto, S. (2018). Local wisdom of Sabang island society (Aceh, Indonesia) in building ecological intelligence to support sustainable tourism. GeoJournal of Tourism and Geosites, 22(2), 393-402. https://doi.org/10.30892/gtg.22210-297.

Atanga, R. A. (2019). Stakeholder views on sustainable community based ecotourism: A case of the Paga crocodile ponds in Ghana. Geojournal of Tourism and Geosites, 25(2), 321-333. https://doi.org/10.30892/gtg.25204-362.

Bentivenga, M., Cavalcante, F., Mastronuzzi, G., Palladino, G. \& Prosser, G. (2019). Geoheritage: The foundation for sustainable geotourism. Geoheritage, 11 (4), 1367-1369. https://doi.org/10.1007/s12371-019-00422-w.

Boschma, R. \& Martin, R. (2010). The Handbook of Evolutionary Economic Geography. Cheltenham: Edward Elgar Publishing Ltd.

Bosma, N., Schutjens, V., \& Stam, E. (2009). Entrepreneurship in European Regions. In J. Leitao \& R. Baptista (Eds.), Public Policies for Fostering Entrepreneurship:A European perspective (pp. 59-89). New York: Springer. https://doi.org/10.1007/978-1-4419-0249-8_4.

Brahmantyo, M. (2014). Geowisata Bali Nusa Tenggara. Bandung, Indonesia: Badan Geologi.

Chin, W. W. (1998). The partial least squares approach for structural equation modeling. In G. A Marcoulides (Ed.), Methodology for business and management. Modern methods for business research (pp. 295336). Mahwah, NJ: Lawrence Erlbaum Associates Publishers.

Çiftçi, Y. \& Güngör, Y (2016). Proposals for the standard presentation of elements of natural and cultural heritage within the scope of geopark projects. Bulletin of Mineral Research and Exploration, 153, 223238. https://doi.org/10.19076/mta.18476.

Dahalan, N., Jaafar, M., \& Rosdi, S. A. M. (2015). Attitude and Entrepreneurial Intention Among Rural Community: the Mediating Role of Entrepreneurial Opportunity Recognition. SHS Web of Conferences. https://doi.org/10.1051/shsconf/20151801005.

Doniz-Paez, J., Becerra-Ramirez, R., Gonzales-Cardenas, E., Guillen-Martin, C., Escobar-Lahoz, E. (2011). Geomorphosites and geotourism in volcanic landscape: The example of La Corona de Lajjal Cinder Cone (El Hierro, Canary Island, Spain). GeoJournal of Tourism and Geosites, 2(8), 185-197.

Dowling, R. K., \& Newsome, D. (2018). Geotourism Destinations - Visitor Impacts and Site Management Considerations. Czech Journal of Tourism, 6(2): 111-129 https://doi.org/10.1515/cjot-2017-0oo6.

Farsani, N. T., Coelho, C., \& Costa, C. (2011). Geotourism and geoparks as novel strategies for socio-economic development in rural areas. International Journal of Tourism Research, 13(1), 68-81. https://doi.org/10.1002/jtr.80o.

Farsani, N. T., Coelho, C., \& Costa, C. (2012). Geotourism and Geoparks as Gateways to Socio-cultural Sustainability in Qeshm Rural Areas, Iran. Asia Pacific Journal of Tourism Research, 17 (1), 30-48. https://doi.org/10.1080/10941665.2011.610145.

Ghozali, I., \& Latan, H. (2015). Partial Least Squares: Konsep, Teknik dan Aplikasi Menggunakan Program SmartPLS 3.o, -2/E. Semarang: Badan Penerbit Universitas Diponegoro.

Ghozali, I. (2006). Structural Equation Modeling Metode Alternatif dengan Partial Least Square (PLS). Semarang: Badan Penerbit Universitas Diponegoro.

Gries, T., \& Naudé, W. (2011). Entrepreneurship and human development: A capability approach. Journal of Public Economics, 95, 216-224. https://doi.org/10.1016/j.jpubeco.2010.11.008.

Hair Jr, J. F., Hult, G., Ringle, C. M., \& Sarstedt, M. (2017). A Primer on Partial Least Squares Structural Equation Modeling. Los Angeles: Sage.

Henseler, J., Ringle, C. M., \& Sarstedt, M. (2014). A new criterion for assessing discriminant validity in variancebased structural equation modeling. Journal of the Academy of Marketing Science, 43(1), 115-135. https://doi.org/10.1007/s11747-014-0403-8.

Hoyle, R. H. (1995). Structural Equation Modeling: Concepts, Issues, and Applications. Thousand Oaks, CA: Sage Publications, Inc.

Idziak, W., Majewski, J. \& Zmyślony, P. (2015). Community participation in sustainable rural tourism experience creation: A long-term appraisal and lessons from a thematic villages project in Poland. Journal of Sustainable Tourism, 23, (8-9), 1-22. http://dx.doi.org/10.108o/09669582.2015.1019513.

Jaafar, M., Dahalan, N., \& Asma, M. R. S. (2014). Local community entrepreneurship: A case study of the Lenggong Valley. Asian Social Science, 1o(10), 226-235. https://doi.org/10.5539/ass.v1on1op226.

Kibler, E. (2013). Formation of entrepreneurial intentions in a regional context. Entrepreneurship and Regional Development, 25(3-4), 293-323. https://doi.org/10.1080/08985626.2012.721008.

Lapinski, M. K., \& Rimal, R. N. (2005). An explication of social norms. Communication Theory, 15(2), 127-147. https://doi.org/10.1093/ct/15.2.127.

Liñán, F., Urbano, D., \& Guerrero, M. (2011). Regional variations in entrepreneurial cognitions: Start-up intentions of university students in Spain. Entrepreneurship and Regional Development, 23(3-4), 187215. https://doi.org/10.1080/08985620903233929. 
Marcoulides, George A., \& Chin, W. W. (2013). You Write, but Others Read: Common Methodological Misunderstandings in PLS and Related Methods. Springer Proceedings in Mathematics and Statistics. https://doi.org/10.1007/978-1-4614-8283-3_2.

Marcoulides, George A., \& Saunders, C. (2006). Editor's Comments - PSL: A Silver bullet? MIS Quarterly, 3o(2), iii-ix.

Newbery, R., \& Bosworth, G. (2014). The character of rural business relations. In Rural Cooperation in Europe: In Search of the "Relational Rurals." Singapore: Palgrave Macmillan. https://doi.org/10.1057/9781137348890.

Newbery, R., Siwale, J., \& Henley, A. (2017). Rural entrepreneurship theory in the developing and developed world. International Journal of Entrepreneurship and Innovation, 18(1), 3-4. https://doi.org/10.1177/1465750316686232.

Newsome, D. \& Dowling, R. (2005). The scope and nature of geotourism . In D. Newsome (Ed.), Geotourism (pp. 3-25). London: Routledge. https://doi.org/10.4324/9780080455334.

Reynolds, P., Bosma, N., Autio, E., Hunt, S., De Bono, N., Servais, I., \& Chin, N. (2005). Global entrepreneurship monitor: Data collection design and implementation 1998-2003. Small Business Economics, 24(3): 205231. https://doi.org/10.1007/s11187-005-1980-1.

Robeyns, I. (2005). The Capability Approach: a theoretical survey. Journal of Human Development, 6(1), 93117. https://doi.org/10.1080/146498805200034266.

Strydom, A.J., Mangope, D., \& Henama, U.S. (2018). Making community-based tourism sustainable: Evidence from the Free State Province, South Africa. GeoJournal of Tourism and Geosites, 24(1), 7-18. https://doi.org/10.30892/gtg.24101-338.

Sternberg, R. (2009). Regional Dimensions of Entrepreneurship. Foundations and Trends in Entrepreneurship, 5(4): 211-340. https://doi.org/10.1561/0300000024.

Thompson, E. R. (2009). Individual entrepreneurial intent: Construct clarification and development of an internationally reliable metric. Entrepreneurship: Theory and Practice, 33, 669-694. https://doi.org/10.1111/j.1540-6520.2009.00321.x.

Vijulie, I., Matei, E., Preda, M., Manea, G., Cuculici, R., \& Mareci, A. (2018). Tourism - A viable alternative for the development of rural mountainous communities. Case study: Eftimie Murgu, Caras-Severin County, Romania. GeoJournal of Tourism and Geosites. 22(2), 419-431. https://doi.org/10.30892/gtg.22212-299.

Wilson, N., \& Martin, L. (2015). Entrepreneurial opportunities for all?: Entrepreneurial capability and the capabilities approach. International Journal of Entrepreneurship and Innovation, 16(3), 159-169. https://doi.org/10.5367/ijei.2015.0189.

Wimbeldon, W.A.P. (1996). National site selection, a stop on the road to a European Geosite list. Geologica Balcanica, 26, 15-27.

Yuliawati, A. K., Sapari, M., Hadian, D., \& Hurriyati, R. (2016). Developing Geotourism as Part of Sustainable Development at Ciletuh Sukabumi, West Java, Indonesia. Journal of Environmental Management and Tourism, VII(1), 57-62. https://doi.org/10.14505/jemt.v7.1(13).05.

*** ARSEL-Community. (2018). Rencana Kerja Tahunan Usaha Pemanfaatan Jasa Lingkungan Hutan Kemasyarakatan Arsel Community Tahun 2018 dan Laporan Pengeloaan Hutan Kemasyarakatan HKm Arsel Community. Retrieved from http://arthawisesa.com/simping/assets/upload/renka/ RENCANA_KERJA_ARSEL_COMMUNITY_TAHUN_2018.pdf.

*** Ministry of Tourism of Indonesia (2018). Penyusunan Masterplan Pengembangan Geopark Pulau Belitung. Retrieved 25 December 2019 from http://eperformance.kemenpar.go.id/dokumen/264-Presentasi \%20Masterplan\%20Geopark\%20Belitung\%20(4\%20desember\%202018)\%20-\%20FINAL.pdf.

*** ProGEO Group (1998). A first attempt at a geosites framework for Europe -an IUGS initiative to support recognition of World heritage and European geodiversity. Geologica Balcanica, 28(3), 5-32.

*** UNESCO. (2018). UNESCO Global Geopark. Retrieved from http://www.unesco.org/new/en/naturalsciences/environment/earth-sciences/unesco-global-geoparks/frequently-asked-questions/what-is-aunesco-global-geopark/.

Submitted:

11.10.2019
Revised:

24.01.2020
Accepted and published online 28.01.2020 